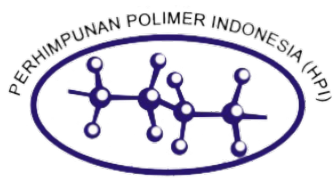

\title{
The Effect of Different Types of Carbon Black on Thermal Charac- teristics of Shape Memory Natural Rubber Vulcanizate
}

\author{
Noor Maryam Setyadewi ${ }^{\mathrm{a}}$, Hesty Eka Mayasari ${ }^{\mathrm{b}}$, Efa Radnawati $^{\mathrm{a}}$ \\ In this research, thermal characteristics of shape memory natural rubber (SMNR) vulcanizate with different types of \\ carbon black filler (N220, N330, N550) were investigated to specify the appropriate type of carbon black for the desired \\ characteristic of the vulcanizate. SMNR vulcanizate prepared by swelling the vulcanizate with stearic acid at $70{ }^{\circ} \mathrm{C}$. The \\ thermogravimetric method was analyzed in a flowing nitrogen atmosphere at a heating rate of $20^{\circ} \mathrm{C} \mathrm{min}{ }^{-1}$. It was found \\ that the initial degradation temperature of the blank vulcanizate $\left(357.37-386.13{ }^{\circ} \mathrm{C}\right)$ was higher than SMNR vulcanizate \\ swollen stearic acid $\left(327.65-359.95^{\circ} \mathrm{C}\right)$ meaning decreased thermal stability of SMNR vulcanizate. The weight loss of the \\ blank vulcanizate at any type of carbon black is lower than SMNR vulcanizate.
}

Dalam penelitian ini, karakteristik termal dari vulkanisat karet alam pengingat bentuk (SMNR) dengan berbagai jenis pengisi karbon hitam filler (N220, N330, N550) diinvestigasi untuk menentukan jenis karbon hitam yang sesuai untuk karakteristik vulkanisat yang diinginkan. Vulkanisat SMNR dibuat dengan merendam vulkanisat dalam lauratan asam stearat pada suhu $70{ }^{\circ} \mathrm{C}$. Metode termogravimetri dianalisis dalam atmosfer nitrogen yang mengalir pada tingkat pemanasan sebesar $20^{\circ} \mathrm{C}$ menit $^{-1}$. Ditemukan bahwa suhu degradasi awal vulkanisat blanko $\left(357,37-386,13{ }^{\circ} \mathrm{C}\right)$ lebih tinggi dari vulkanisat SMNR yang telah direndam asam stearat $\left(327,65-359,95{ }^{\circ} \mathrm{C}\right)$ yang berarti terjadi penurunan stabilitas termal vulkanisat SMNR. Penurunan berat dari vulkanisat blanko pada semua jenis karbon hitam lebih rendah dari vulkanisat SMNR.

Keywords: Carbon black, natural rubber, shape memory, thermal characteristic, thermogravimetric.

\section{Introduction}

Natural rubber (NR) are attractive materials for shape memory polymers (SMP) because their properties, such as inexpensive, have good mechanical properties and high elasticity. Shape memory polymers (SMPs) are functional materials that are programmed to change their shape in response to an external stimulus, such as temperature. As SMPs are fabricated from a variety of polymeric materials, they have attracted interest in applications in a varied range of areas including textiles, medicine, and aerospace. ${ }^{1}$

For knowing their processing behavior and to selecting the suitable material for a given application, polymer technologist requires knowledge about their thermal stability. ${ }^{2}$ Thermal stability means the ability of a material to maintain the required properties such as toughness, strength, or elasticity at a given temperature. ${ }^{3}$ This thermal stability is different for each polymer, so its need to be done to determine the performance of a material to be used before it is degraded. ${ }^{4}$ One method for studying the thermal stability of materials is thermogravimetry. ${ }^{5}$ Thermogravimetry can be defined as the change in mass of the sample as a function of temperature when it is subjected to a controlled temperature program. The resulting mass change versus temperature curve serves the data regarding

a. Center for Leather, Rubber, and Plastics, Yogyakarta, Indonesia.

b. Center for Research and Standardization of Surabaya, Surabaya, Indonesia.

† Corresponding author: nmsetyadewi@gmail.com. the thermal stability and composition of the initial sample, intermediates, and the residue. ${ }^{6}$ Much research on the degradation of different rubbers using thermal analysis techniques has already been reported. Jovanovic et al. ${ }^{7}$ investigated the influence of two types of carbon black (CB) filler N330 and N990 on elastomeric composites based on acrylonitrile-butadiene rubber (NBR), Song et al. ${ }^{8}$ discussed six kinds of $\mathrm{CB}$ were filled in natural rubber composites and the effect of $\mathrm{CB}$ on thermal conductivity of the composites.

In the present research, we have examined the thermal properties of shape memory natural rubber (SMNR) vulcanizate by thermogravimetric analysis. This research aim is to understand how different types of $C B$ and swelling treatment with stearic acid on vulcanizate influences the thermal stability of the SMNR vulcanizate.

\section{Experimental Methods}

Materials

SMNR vulcanizate was made from natural rubber (NR) Ribbed Smoke Sheet-1, activator Zinc oxide (ZnO, Indoxide) and stearic acid (Aflux 42M Rhein Chemie), different types of carbon black was used as filler (N220, N330, N550), antidegradant 2,2,4-Trimethyl-1,2-Dihydroquinoline (TMQ) and N-(1,3-Dimethylbutyl)- $\mathrm{N}^{\prime}$-phenyl-p-phenylenediamine (6PPD, Starchem), paraffinic oil (Indrasari), Accelerator N-Cyclohexy-2-Benzothiazole Sulfonamide CBS (CZ), vulcanizing agent sulfur (Miwon). 


\section{Method}

The formulation of compounds with different types of carbon black is shown in Table 1, based on a total of 100 parts of NR by weight.

Table 1. SMNR formulation

\begin{tabular}{llll}
\hline \multirow{2}{*}{ Material } & \multicolumn{3}{l}{ An Amount (phr, per hundred rubber) } \\
\cline { 2 - 4 } & N22 & N33 & N55 \\
\hline NR & 100 & 100 & 100 \\
ZnO & 0.2 & 0.2 & 0.2 \\
Stearic acid & 1.4 & 1.4 & 1.4 \\
Carbon Black & 3 & 3 & 3 \\
TMQ & 1 & 1 & 1 \\
6 PPD & 0.5 & 0.5 & 0.5 \\
Paraffinic Oil & 3 & 3 & 3 \\
CBS & 1 & 1 & 1 \\
Sulfur & 2 & 2 & 2 \\
\hline
\end{tabular}

NR was masticated on a two-roll mill, then additives are added, and the compound was slabbed. Then the compound stored at the conditioned room at a temperature of $23 \pm 2{ }^{\circ} \mathrm{C}$ for 24 hours. After that, a rheometer test was carried out at a temperature of $150{ }^{\circ} \mathrm{C}$ to get the optimum cure time data.

Blank SMNR vulcanizate was made in a hydraulic press (Toyoseiki A-652) at $150{ }^{\circ} \mathrm{C}$ with a pressure of $150 \mathrm{~kg} \mathrm{~cm}^{-2}$ with timebased on the rheometer data. SMNR vulcanizates were swollen in molten stearic acid $(100 \% \mathrm{w} / \mathrm{w})$ at $70{ }^{\circ} \mathrm{C}$ for $1.0 \mathrm{~h}$ then quenching in a beaker of a $10^{\circ} \mathrm{C}$ water. ${ }^{1}$

The thermogravimetric analysis was done using Shimadzu DTG$60 \mathrm{H}$ in nitrogen with a flow rate of $5 \mathrm{~mL} \mathrm{~min}^{-1}$ at $30-800^{\circ} \mathrm{C}$. Around 9-13 mg SMNR sample was heated with $20{ }^{\circ} \mathrm{C} \mathrm{min}-1$ heating rate using an alumina pan.

\section{Result and Discussion}

Thermogravimetry (TG) is the most used technique to study thermal degradation. This technique consists of preheating the sample to a given temperature (TO) and then starting the experiment with a fixed nominal heating rate. $^{9}$

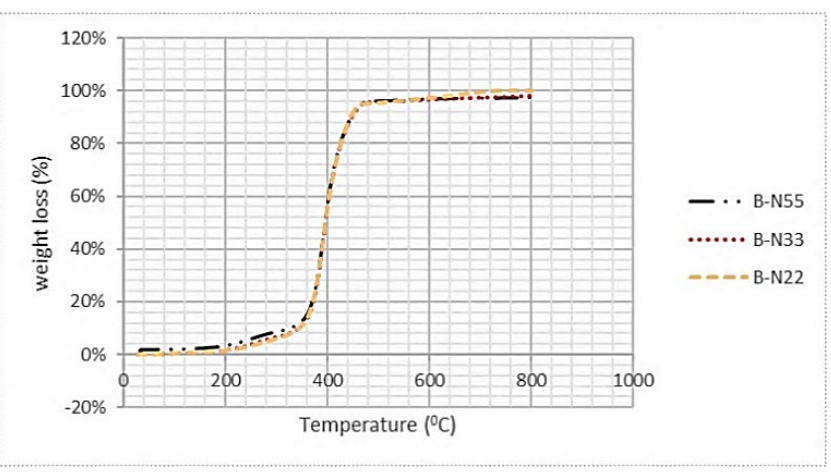

(a)

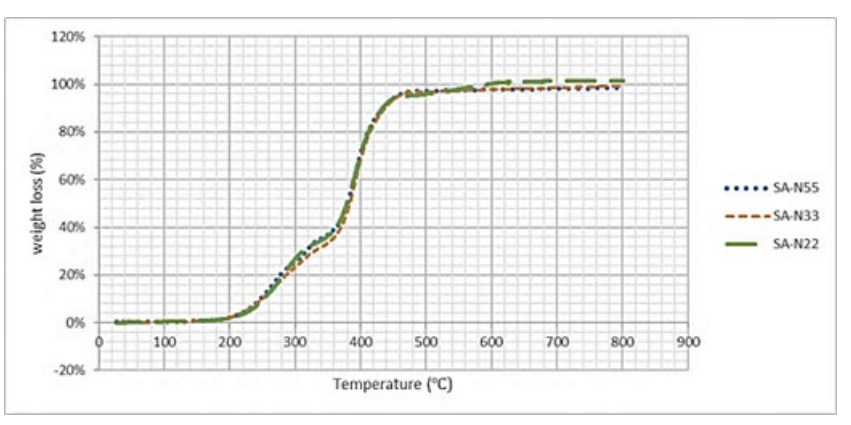

(b)

Figure 1. Thermogravimetric (TG) curve of SMNR vulcanizate (a) Blanko sample; (b) Treated sample.

The thermal degradation of SMNR vulcanizate filled by N220, N330, and N550 types of CB presented in Figure 1. Figure 1 presents that the TG curve has similar areas for all formulas, both in the blank (Figure 1a) and treated samples (Figure 1b). May it cause by the formulation of SMNR are constant. The degradation of the blank sample (B-N22, B-N33, B-N55) takes place in a single step (i.e., the region from 350 to $431^{\circ} \mathrm{C}$ ). It is also reported below that temperature, and NR is quite stable. ${ }^{3}$ The weight loss observed is $95.69 \%$ until $100 \%$. In the case of the treated sample (Figure 1b), the degradation takes place in two stages. The first-step degradation occurs in the temperature region $231-307^{\circ} \mathrm{C}$, and the weight loss is $32.79 \%$. The second-step degradation starts at $367{ }^{\circ} \mathrm{C}$ and ends at $428^{\circ} \mathrm{C}$. The percent of weight loss in this region is $68.14 \%$.

One of the most important factors that can influence the initial TG behavior is the strength of the bonds in the main polymer chain, the cross-linking density, i.e., the concentration of free chain ends whose extraction would lead to mass loss and polymer chain flexibility which is affected by polymer structure and cross-linking density. ${ }^{7}$

The derivative thermogravimetric curve presented in Figure 2, it shows that the degradation of blank SMNNR vulcanizate occurs in one stage (Figure 2a). There is one sharps peak that indicates the temperature when the highest mass degradation occurs. The DTG curves show that Blank N22, N33, N55 almost have the same behavior, while Blank N55 provides a lower peak.

Figure $2 \mathrm{~b}$ shows DTGA curves for treated samples SA-N22, SAN33, SA-N55, that there are two areas of weight loss between 230 and $450{ }^{\circ} \mathrm{C}$, producing two peaks on DTGA curves (Figure $2 \mathrm{~b}$ ). The first peak at $\sim 230{ }^{\circ} \mathrm{C}$ is due to the presence of volatile materials such as stearic acid, which is released at a temperature of around $300{ }^{\circ} \mathrm{C}$ and proceeds rapidly with increasing temperature until about $400{ }^{\circ} \mathrm{C}$. The second step proceeds until the final temperature around $450-500{ }^{\circ} \mathrm{C}$ indicated degradation of natural rubber. The complete degradation reaction at $350-430{ }^{\circ} \mathrm{C}$ temperature range with $100 \%$ weight loss for SA-N22 vulcanizate, $97.96 \%$ for SA-N33 vulcanizate and $98.40 \%$ for SA-N55 vulcanizate. 


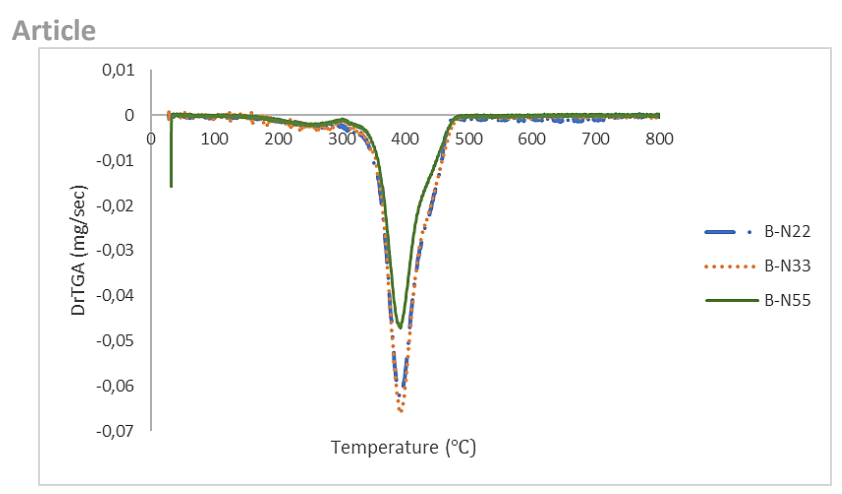

(a)

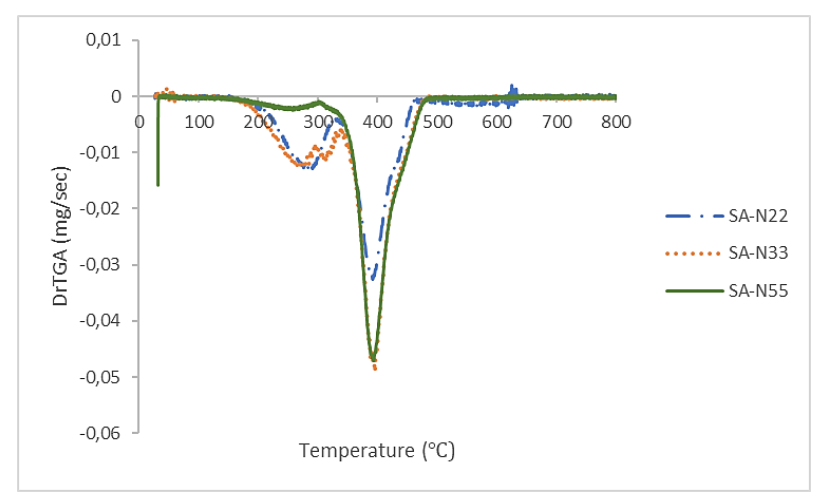

(b)

Figure 2. The derivative thermogravimetric curves of the SMNR vulcanizate.

\section{Conclusions}

From the obtained results, it can be concluded that the initial degradation temperature of the blank vulcanizate (357.37$386.13^{\circ} \mathrm{C}$ ) was higher than the SMNR vulcanizate swollen stearic acid $\left(327.65-359.95{ }^{\circ} \mathrm{C}\right)$ meaning decreased thermal stability of SMNR vulcanizate. The weight loss of the blank vulcanizate at any type of carbon black is lower than SMNR vulcanizate.

\section{Conflicts of Interest}

There are no conflicts to declare.

\section{Acknowledgments}

The authors would like to acknowledge the Center of Leather, Rubber, and Plastics - Ministry of Industry Indonesia for financial support.

\section{References}

1 N. R. Brostowitz, R. A. Weiss and K. A. Cavicchi, Facile Fabrication of a Shape Memory Polymer by Swelling Cross-Linked Natural Rubber with Stearic Acid, ACS Macro Lett., 2014, 3(4), 374377.

2 A. Sasikala and A. Kala, Thermal Stability and Mechanical Strength Analysis of EVA and Blend of EVA with Natural Rubber, Mater. Today Proc., 2018, 5(2), 8862-8867.

3 J. T. Varkey, S. Augustine and S. Thomas, Thermal Degradation of Natural Rubber/Styrene Butadiene Rubber Latex Blends by Thermogravimetric Method, Polym. - Plast. Technol. Eng., 2000, 39(3), 415-435.

4 H. E. Mayasari and A. Yuniari, Kinetic Analysis of Thermal Degradation of NR/EPDM Blends with Maleic Anhydride as Compatibilizer: The Effect of the Reactive Accelerators, Maj. Kulit, Karet, dan Plast., 2017, 33(2), 79.

5 H. Nabil, H. Ismail and A. R. Azura, Thermal Stability and Aging Characteristics of (Natural Rubber)/(Waste Ethylene-Propylene-Diene Monomer Terpolymer) Blends, J. Vinyl Addit. Technol., 2014, 1-9.

6 S. Gul, A. A. Shah and S. Bilal, Calculation of Activation Energy of Degradation of Polyaniline-Dodecylbenzene Sulfonic Acid Salts via TGA, J. Sci. Innov. Res., 2013, 2(3), 673-684.

7 S. Samaržija-Jovanović, V. Jovanović, G. Marković and M. Marinović-Cincović, The Effect of Different Types of Carbon Blacks on the Rheological and Thermal Properties of Acrylonitrile Butadiene Rubber, J. Therm. Anal. Calorim., 2009, 98(1), 275-283.

8 J. ping Song, K. yan Tian, L. xiang Ma, W. Li and S. chune Yao, The Effect of Carbon Black Morphology to the Thermal Conductivity of Natural Rubber Composites, Int. J. Heat Mass Transf., 2019, 137, 184-191.

9 R. Ebrahimi-Kahrizsangi and M. H. Abbasi, Evaluation of Reliability of Coats-Redfern Method for Kinetic Analysis of Non-Isothermal TGA, Trans. Nonferrous Met. Soc. China (English Ed.), 2008, 18(1), 217-221. 